\title{
EXPLORASI DESAIN PASAR AGROBISNIS DENGAN PENDEKATAN ARSITEKTUR VERNAKULAR DI KOTA MAKASSAR
}

\section{Marwati*1, Burhanuddin ${ }^{2}$, Abdul Umar ${ }^{3}$ \\ Arsitektur UIN-Alauddin Makassar , Arsitektur UIN-Alauddin Makassar, Arsitektur UIN- Alauddin Makassar *1mar.ambodalle@gmail.com, 2amin.burhanuddin@gmail.com, 33umar@gmail.com}

\begin{abstract}
Abstrak_ Kota Makassar sebagai pusat perdagangan wilayah timur merancang strategi pembangunan di bidang ekonomi khususnya pasar. Berdasrkan RTRW (Rencana Tata Ruang Wilayah) Kota Makassar tahun 2010 - 2030 menyatakan bahwa Kelurahan Daya Kota Makassar termasuk dalam kawasan industri dan wisata belanja. Tujuan dari penulisan ini ialah merancang strategi Pasar Agrobisnis yang efektif dan efisien dengan pendekatan Arsitektur vernakuler. Metode pembahasan yang digunakan adalah eksplorasi desain dengan menguraikan masalah yang ada melalui studi literatur dan survei lapangan, mengkaitkannya dengan beberapa variabel yang berpengaruh, sehingga dapat dirumuskan sebagai acuan untuk dijadikan bahan transformasi ke dalam desain. Hasil dari penulisan ini memberi model gagasan konsep perancangan Pasar Agrobisnis yang efektif dan efisien dengan pendekatan Arsitektur vernakuler.
\end{abstract}

Kata kunci : Pasar Agrobisnis; Arsitektur Vernakuler; Makassar.

\footnotetext{
${ }^{1}$ Dosen Jurusan Arsitektur Fakultas Sains \& Teknologi UIN-Alauddin Makassar

${ }^{2}$ Dosen Jurusan Arsitektur Fakultas Sains \& Teknologi UIN-Alauddin Makassar

${ }^{3}$ Alumni Jurusan Arsitektur Fakultas Sains \& Teknologi UIN-Alauddin Makassar, angkatan 2016
} 


\section{PENDAHULUAN}

Kota Makassar sebagai Ibukota propinsi Sulawesi Selatan yang merupakan pintu gerbang pembangunan dan perdagangan di Kawasan Indonesia Timur (KTI). Secara geografis kota Makassar terletak $5^{\circ}, 09^{\prime}$ LS dan $119^{\circ}, 20^{\prime}$ LU dengan ketinggian antara $0 \mathrm{~s} / \mathrm{d} 20 \mathrm{M}$ diatas permukaan laut. Dengan letak stratengis ini mendorong Sulawesi Selatan sebagai sentral produksi holtikultura hasil dari daerah-daerah yang ada di Sulawesi Selatan. Laju pertumbuhan ekonomi di Indonesia pada tahun 2012 yang lalu mencapai 6,3 \%, sehingga index pertumbuhan selama beberapa tahun ini mencapai $7.6 \%$ pertahun. (MakassarKota.go.id)

Daerah Sulawesi Selatan sebagai penghasil hasil pertanian, terbagi pada dua sektor yang sering disebut sektor utara dan sektor selatan. Adapun sektor utara meliputi : Kabupaten Maros, dengan hasil pertaniannya yaitu beras, jagung, ubi kayu, kacang tanah dan kacang hijau, untuk hasil pertanian Kabupaten Pangkep yaitu beras, jagung, kedelai, kacang tanah, ubi jalar, dan kacang hijau. Hasil pertanian dari Kabupaten Barru yaitu beras, jagung, kedelai, kacang tanah, ubi jalar dan kacang hijau. Untuk hasil pertanian dari Kotamadya Pare-pare yaitu padi, kacang mente, biji kakao dan palawija. Sedangkan hasil petanian dari Kotamadya Palopo yaitu padi, jagung, kedelai, kacang tanah, ubi jalar dan kacang hijau, dan daerah lain yang berada di daerah sektor utara, sedangkan sektor selatan meliputi : Kabupaten Gowa dengan hasil pertaniannya yaitu padi, ubi kayu, kacang tanah dan kedelai.

Hasil pertaniah Kabupaten Takalar yaitu padi, jagung, ubi kayu, kacang tanah, kedelai dan kacang hijau. Sedangkan hasil pertanian Kabupaten Jeneponto yaitu beras, jagung, ubi kayu, kacang tanah, kedelai dan kacang hijau. Untuk hasil pertanian Kabupaten Sinjai yaitu beras, jagung, ubi kayu, kacang tanah dan ubi jalar. Sementara hasil pertanian dari Kabupaten Bulukumba yaitu beras, jagung, ubi kayu, kacang tanah, kedelai, kacang hijau dan Daerah sekitar sektor selatan. Peranan Daerah Sulawesi Selatan khususnya Kota Makassar sebagai pusat perdagangan wilayah timur sangat dibutuhkan sekali dalam membangun ekonomi. (sel-sel.go.id)

Seiring dengan bertambahnya penduduk di Kota Makassar saat ini maka menuntut untuk diadakannya penambahan dan perbaikan fungsi fasilitas ekonomi dan perdagangan di Kota Makassar, Pasar yang merupakan salah satu fasilitas ekonomi dan perdagangan pada suatu kota memiliki peranan yang sangat penting dalam memenuhi kebutuhan masyarakat, menggerakkan perekonomian di suatu daerah dan meningkatkan pendapatan asli daerah. Dalam hal ini pasarpasar di Kota Makassar.

Pasar Agrobisnis yang mampu menampung berbagai macam hasil pertanian yang nantinya akan di distribusikan ke pasar-pasar yang kusus untuk grosir di Kota Makassar. Namun pasarpasar saat ini, diidentik dengan kemacetan, kebisingan, kotor, dan tidak aman. Untuk itu diperlukan adanya pasar Agribisnis di Kota Makassar yang mampu meminimalisir kemacetan kebersihan, dan keamanan dalam bertransaksi, sehingga dapat mewujudkan Pasar Agrobisnis yang sehat, aman, dan nyaman. Pasar Agrobisnis ini juga diharapkan mampu menyediakan fasilitas-fasilitas perdagangan demi kelancaran aktivitas perdagangan di Kota Makassar sehingga dalam perkembangan selanjutnya, diharapkan Pasar Agrobisnis dapat menjadi ikon baru yang menjadi kebanggaan Kota Makassar.

\section{METODOLOGI}

Metode pembahasan yang digunakan adalah analisis sintesa, yaitu menguraikan masalah Nyang ada melalui studi literatur dan survei lapangan, mengkaitkannya dengan beberapa variabel 
yang berpengaruh, sehingga dapat dirumuskan sebagai acuan untuk dijadikan bahan transformasi ke dalam desain.

1. Studi Literatur

Melalui literatur-literatur dan buku-buku yang berkaitan dengan penulisan untuk mendapatkan teori, spesifikasi, dan karakteristik pasar induk serta aspek-aspek arsitektural yang dapat dijadikan landasan dalam proses perancangan.

2. Studi Banding

Melakukan studi perbandingan di beberapa Pasar Agrobisnis Tradisional dengan survei lansung dan obsevasi yang sesuai dengan konsep arsitektur Tradisional sebagai acuan dalam merancang Pasar Agrobisnis Dengan Pendekatan Vernakular di Kota Makassar.

3. Penentuan Site

Penetuan site tidak terlepas dari pengaruh timbal balik dari kegiatan-kegiatan / fasilitas lainnya, baik itu kegiatan yang mendukung ataupun yang tidak mendukung. Adapun kelompokkelompok kegiatan yang mendukung keberadaan pasar Agrobisnis dan memiliki hubungan langsung, yaitu terminal induk Daya, pasar grosir, pertokoan dan industri (industri pengolahan makanan dan lain-lain), sehingga lokasi site sebisa mungkin berada pada daerah yang berpotensi dan mudah dijangkau oleh para pedagang, konsumen dan pengunjung.

Berdasarkan hal tersebut, maka penetuan site harus didasarkan pada pertimbangan sebagai berikut :

a. Dari segi peruntukan lahan/tata guna lahan

Sebagai bangunan yang bersifat komersial, maka Pasar Agrobisnis dengan Pendekatan Arsitektur Vernakular perlu berada di lokasi yang tata guna lahannya diperuntukkan untuk fasilitas perdagangan dan jasa.

b. Dari segi aksebilitas

Lokasi harus mempertimbangkan kemudahan pencapaian baik dari dalam maupun luar kota. Hal ini berkaitan dengan kualitas jalan, faktor keamanan terhadap kecelakaan dan arus sirkulasi kendaraan dengan pencapaian yang tidak mengganggu tapak.

c. Dari segi lingkungan

Lokasi perlu memiliki fasilitas-fasilitas yang dapat mendukung bangunan yang bersifat komersial, yaitu strategis terhadap pusat kota, yang meliputi daerah perkantoran, permukiman, pertokoan/perbelanjaan serta mempunyai nilai prestise yang tinggi.

d. Dari segi utilitas kota

Lokasi harus memiliki kelengkapan infrastruktur kota, yaitu jaringan air bersih, listrik dan pembuangan air kotor untuk menunjang kegiatan bangunan.

e. Kenyamanan dan daya tarik lokasi

Karena bangunan ini bersifat komersial dengan sasaran konsumen semua lapisan masyarakat, maka diperlukan tempat yang nyaman dan menarik sehingga masyarakat menjadi tertarik untuk datang.

f. Kondisi topografi dan space yang tersedi

Bangunan Pasar Argobisnis ini memerlukan lahan yang relatif luas untuk menunjang aktifitas dalam kawasan pasar, kususnya untuk kelancaran keluar masuk kendaraan, baik besar maupun kecil yang mengangkut pengunjung maupun barang.

Berdasarkan persyaratan tersebut, maka dipilih lokasi untuk penempatan bangunan Pasar Agrobisnis Dengan Pendekatan Arsitektur Vernakular di Kota Makassar yang terletak di Jl. Kapasa Raya (Kecamatan Biringkanaya Kelurahan Daya) dengan luas $\pm 5,4 \mathrm{Ha} \mathrm{Km}^{2}$, dengan jumlah penduduk di kecamatan Biringkanaya 130.651 jiwa. 


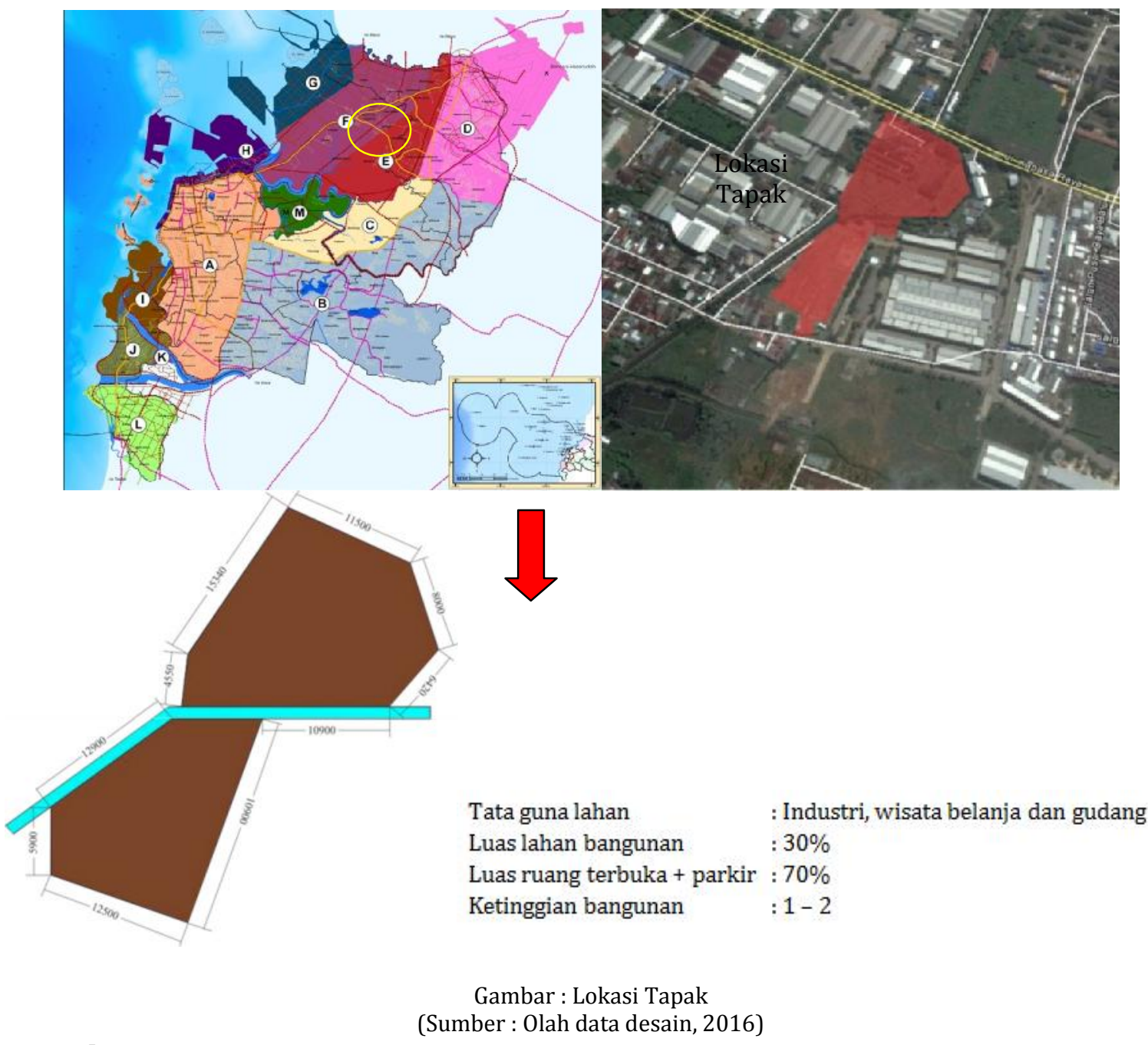

\section{Potensi Lokasi :}

(Sumber : Olah data desain, 2016)

1. Aksebilitas (tingkat kemudahan pencapaian) menuju lokasi baik dari kota maupun permukiman di sekitarnya sangat baik. Terdapat jalan raya concrete hotmix yang menghubungkan kota Makassar dengan kabupaten lainnya yang ada di sulawesi selatan

2. Lahan yang luas $\pm 2,7 \mathrm{Ha}$ sangat potensial untuk dijadikan Pasar Agrobisnis Dengan Pendekatan Arsitektur Vernakular.

3. Posisi tapak yang berada tidak jauh dari pemukiman masyarakat, menjadikan lokasi perencanaan banyak dikunjungi. 


\section{HASIL DAN PEMBAHASAN}

\section{A. Konsep tata massa}

Building coverage ratio sebesar 30 : 70. Dimana lahan yang terbangun sebagai lantai dasar bangunan sebesar 30\% dari luas tapak. Penggunaan 30\% lahan bangunan efektif untuk menyediakan banyak ruang terbuka dalam tapak yang dapat memberikan keleluasaan untuk menempatkan bangunan di tengah tapak sehingga semua sisi bangunan dapat memperoleh akses view kelingkungan sekitar. Konsep zoning dibagi menjadi 2 yaitu zoning hor`izontal (tapak) dan zoning vertikal (bangunan).

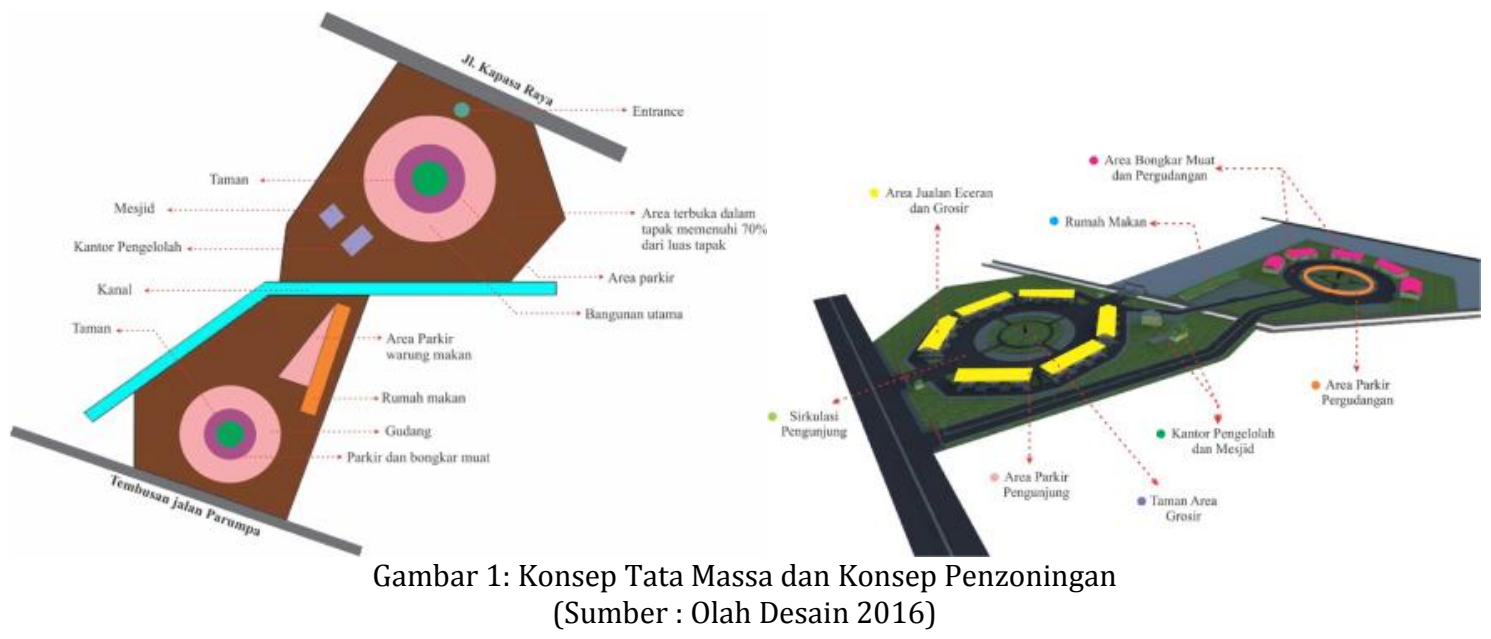

Sirkulasi yang terjadi pada site terdiri dari sirkulasi manusia dan sirkulasi kendaraan. Pada sirkulasi manusia, yang perlu diperhitungkan adalah : 1) Pembuatan pedestrian berdasarkan arah arus pengunjung dengan badan jalan, untuk memberi rasa aman dan menghindari gangguan arus kendaraan. 2) Penyediaan halte kendaraan untuk memudahkan pengunjung mendapatkan kendaraan angkutan umum tanpa gangguan arus kendaraan. 3) Pencapaian yang mudah pada bangunan pasar serta jalur sirkulasi yang bebas dari pedagang kaki lima.

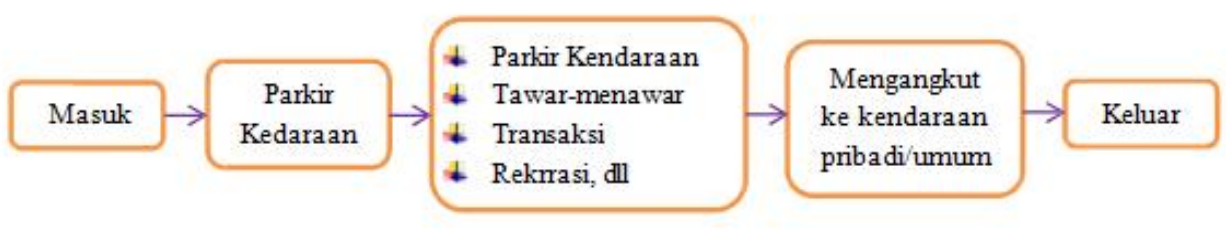

Gambar 2: Skema Sirkulasi pada Manusia

(Sumber : Olah Data Penulis 2016)

Sirkulasi Kendaraan yang perlu diperhatikan adalah arah datangnya konsumen barang dan pola jalan/arah lalu lintas. Konsep perancangan Pasar Agrobisnis terjadi dua pergerakan utama pada arus kendaraan yaitu kendaraan yang membawa komoditi masuk dan membawa komoditi keluar. Untuk memperlancar arus sirkulasi, pemisahan jalur distribusi menjadi sangat penting. Arah lalu lintas sebaiknya satu arah dengan pertimbangan agar arus kendaraan dan barang dapat berjalan lancar. 


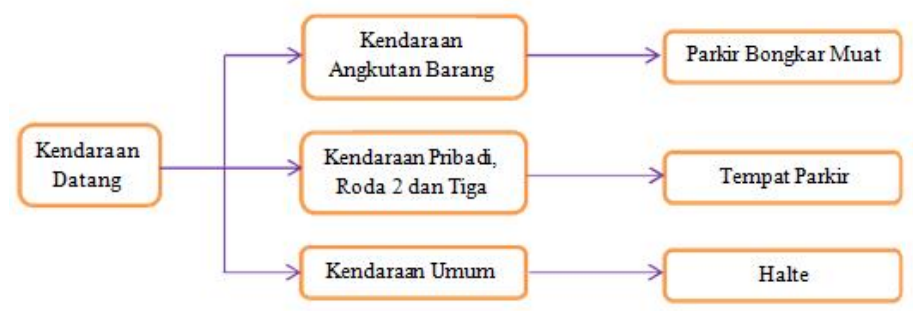

Gambar 3: Skema Sirkulasi pada Kendaraan (Sumber : Olah Data Penulis 2016)

\section{B. Vegetasi dan Kebisingan}

Peningkatan vegetasi sangat dibutuhkan pada tapak untuk menjaga kondisi tanah, lingkungan tapak serta mengurangi kebisingan dan polusi udara dari kendaraan.

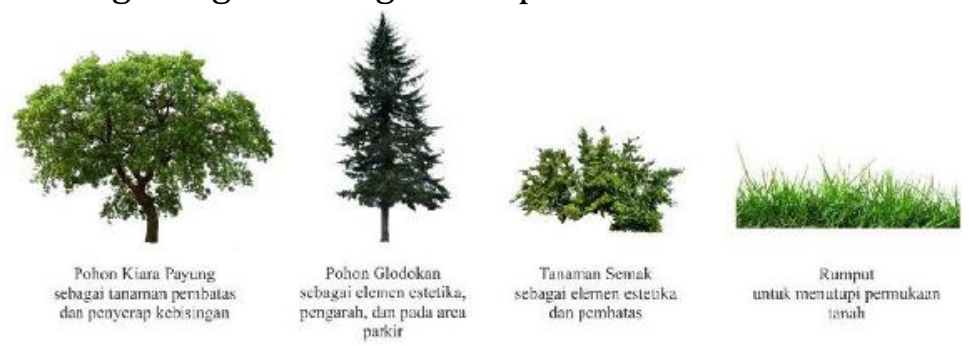

Gambar 4: Vegetasi

(Sumber : Olah Desain 2016)

\section{Konsep Bentuk Bangunan dan Struktur}

Bentuk bangunan merupakan hasil pengembagan dari bentuk dasar dari rumah panggung Bugis Makassar, namun tidak beda jauh dari rumah adat bugis Makassar di karenakan di sesuaikan dengan tema atau penekanan judul, yaitu Pasar Agrobisinis dengan Pendekatan Arsitektur Vernakular di Kota Makassar.
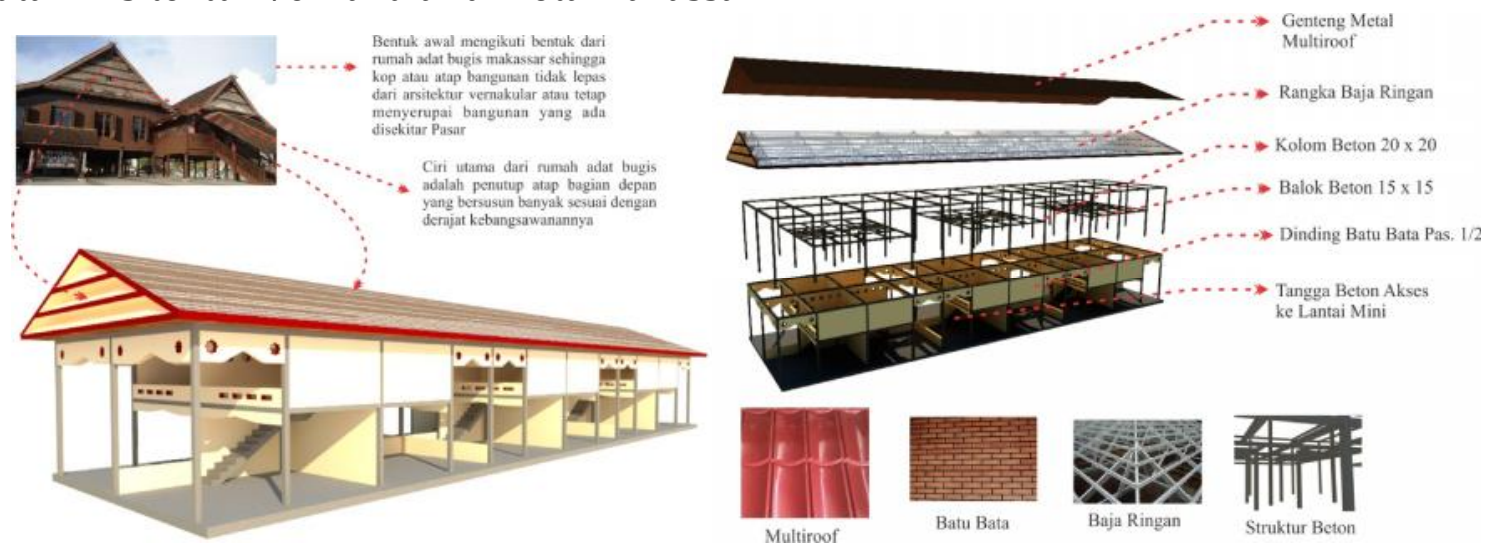

Gambar 5: Konsep Bentuk dan Struktur Material

(Sumber : Olah Desain 2016)

\section{Konsep Vernakuler}

Konsep ruang luar terdapat ciri bentuk Vernakular yang lebih banyak menampilkan unsur alami. Menurut Turan (1990) dalam buku Vernacular Architecture, arsitektur vernakular adalah arsitektur yang berkembang dari arsitektur rakyat yang lahir dari masyarakat etnik dan berjangkar pada tradisi etnik, serta dibangun oleh tukang berdasarkan pengalaman, meggunakan teknik material lokal serta merupakan jawaban atas setting lingkungan tempat bangunan tersebut berada dan selalu membuka untuk terjadinya transformsi. 
1. Pintu gerbang

Merupakan elemen ruang luar yang pertama disaksikan oleh pengunjung. Terletak di area pintu masuk tapak. Merupakan masa pertama yang mendapat perhatian umum. Bentuk gerbang diupayakan berciri lingkungan setempat yang tidak kaku. Pintu gerbang ini berfilosofi dari bentuk atap rumah warga setempat, sehingga dapat tersesuaikan dengan konsep bangunan Pasar Agrobisnis Dengan Arsitektur Vernakuler

2. Pedestrian

Merupakan jalan setapak sarana sirkulasi tapak berupa paving block yang di tata secarah alamia.

3. Sclupture

Merupakan elemen simbolik mencerminkan karakteristik Pasar Vernakular dan ciri khas lingkungan setempat.

4. Wadah untuk pedagang tidak tetap dan pedagang kaki lima.

Berupa tenda-tenda yang tidak permanen dimana kapasitas 1 tenda dapat menampung 3 pedagang sehingga kesan rekreatif, rapi dan teratur dapat tercipta dan dapat mengakomodir para pedagang tersebut.

5. Noise / Kebisingan

Pada umumnya, area yang akan dijadikan sebagai area pengembangan tidak berpengaruh pada kebisingan kendaraan yang disebabkan letaknya yang jauh dari jalan. Kebisingan yang terjadi dalam tapak (dari area parkir maupun kendaraan pengelola) di desain dengan memposisikan area atau kawasan parkir jauh dari area privat serta dengan menata vegetasi di sekitar tapak atau pasar. Pada daerah mempunyai tingkat kebisingan yang cukup tinggi karena berada dekat dengan jalan utama yaitu jalan Kima III oleh karena itu perencanaan lansekap yang baik dibutuhkan untuk tapak tersebut agar kebisingan yang terjadi di luar tapak tidak mengganggu aktivitas yang terjadi di dalam tapak ataupun di dalam bangunan pasar tersebut.

\section{E. Tata Ruang / Layout Bangunan}

1. Besaran Ruang Grosir dan Eceran

Bangunan grosir dan eceran berjumlah 6 unit yang masing-masing per unitnya terdiri dari dua lantai, yang mana lantai satu difungsikan sebagai area jualan grosir dan juga eceran, untuk lantai dua atau lantai mini di fungsikan sebagai area kasir sekaligus kantor dan juga penyimpanan barang jualan grosir.

Besaran ruang yang dibutuhkan untuk lantai satu yaitu untuk area bongkar muat barang kusus grosir seluas $450 \mathrm{~cm} \times 250 \mathrm{~cm}=11,25 \mathrm{~m}^{2}$ sedangkan untuk area jualan eceran seluas $350 \mathrm{~cm} \times 450 \mathrm{~cm}=15,75 \mathrm{~m}^{2}$ jadi total luas keseluruhan untuk area bongkar muat barang dan grosir untuk satu unitnya adalah $27 \mathrm{~m}^{2}$ yang mana dalam satu bangunan terdapat 12 unit kios jadi total luas keseluruhan bangunan grosir dan eceran yaitu $324 \mathrm{~m}^{2} \mathrm{x}$ 6 unit bangunan grosir dan eceran $=1944 \mathrm{~m}^{2}$

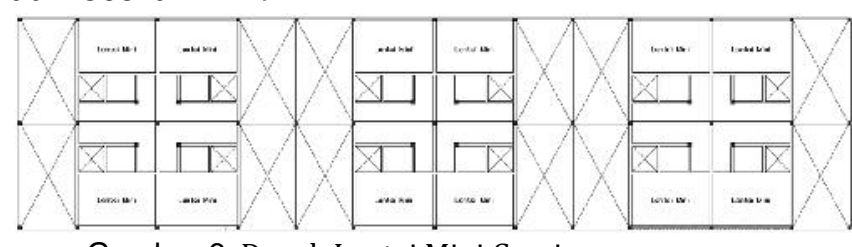

Gambar 6: Denah Lantai Mini Grosir (Sumber : Olah Desain 2016) 
Besaran Ruang yang dibutuhkan untuk lantai dua atau lantai mini yaitu, untuk area penyimpanan barang seluas $225 \mathrm{~cm} \times 350 \mathrm{~cm}=7,87 \mathrm{~m}^{2}$ sementara ruang untuk area kasir seluas $120 \mathrm{~cm} \times 125 \mathrm{~cm}=1.5 \mathrm{~m}^{2}$, total luasan ruang untuk lantai mini per unitnya adalah $9,40 \mathrm{~m}^{2} \times 12$ unit kios dalam satu bangunan $113 \mathrm{~m}^{2} \times 6$ bangunan $=678 \mathrm{~m}^{2}$.

2. Besaran Ruang Gudang

Bangunan untuk gudang ada lima unit yang mana dalam satu unitnya terbagi dalam sepuluh petak, luasan satu petaknya adalah $400 \mathrm{~cm} \times 400 \mathrm{~cm}=16 \mathrm{~m}^{2} \times 10$ petak per gudang $=160 \mathrm{~m}^{2}$, luas ruang untuk selasar gudang yaitu $400 \mathrm{~cm} \times 3200 \mathrm{~cm}=128 \mathrm{~m}^{2}$, jadi total keseluruhan untuk satu unit gudang adalah $288 \mathrm{~m}^{2}$ x 5 unit bangunan gudang $=1440$ $\mathrm{m}^{2}$.

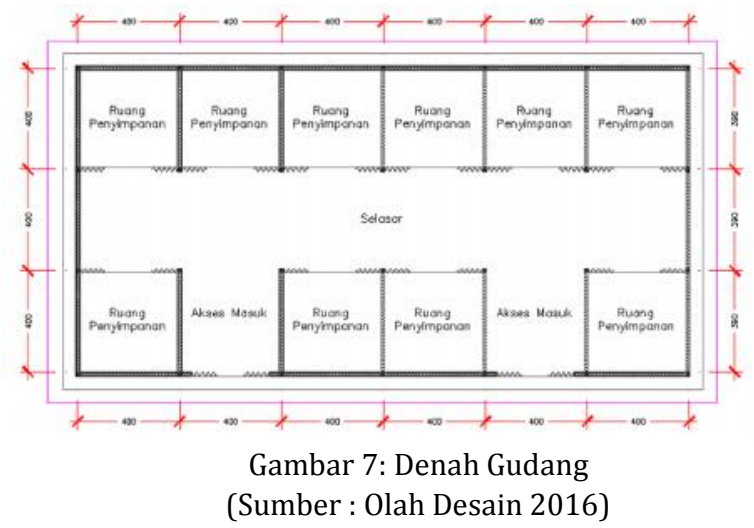

3. Besaran Ruang Rumah Makan

Rumah makan terdiri dari satu unit yang di dalamnya terdapat sepuluh petak untuk ruang masak dan luasan untuk satu petaknya adalah $600 \mathrm{~cm} \times 300 \mathrm{~cm}=18 \mathrm{~m}^{2}$, untuk luasan ruang makan yaitu $300 \mathrm{~cm} \times 600 \mathrm{~cm}=18 \mathrm{~m}^{2}$, total luas ruang dalam satu petaknya adalah $36 \mathrm{~m}^{2} \times 10$ total keseluruhan petak rumah makan $=360 \mathrm{~m}^{2}$.

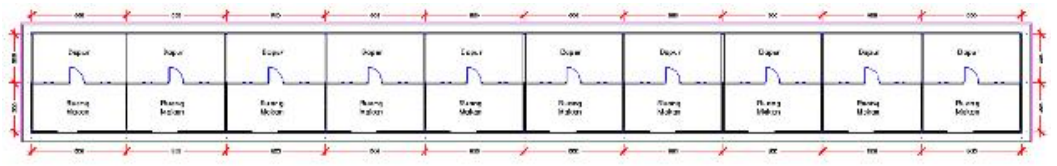

Gambar 8: Denah Rumah Makan

(Sumber : Olah Desain 2016)

4. Kantor Pengelolah dan Mesjid

Kantor pengelolah terdiri dari dua lantai yang besaran ruangnya sebagai berikut Besaran ruang lantai 1.

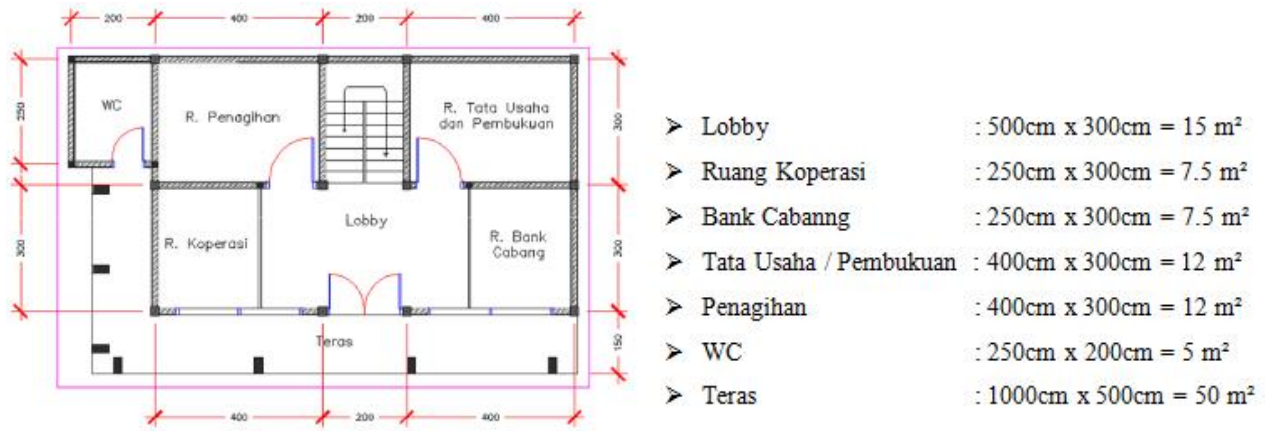

Gambar 9: Denah Lantai 1 Kantor Pengelolah (Sumber : Olah Desain 2016) 


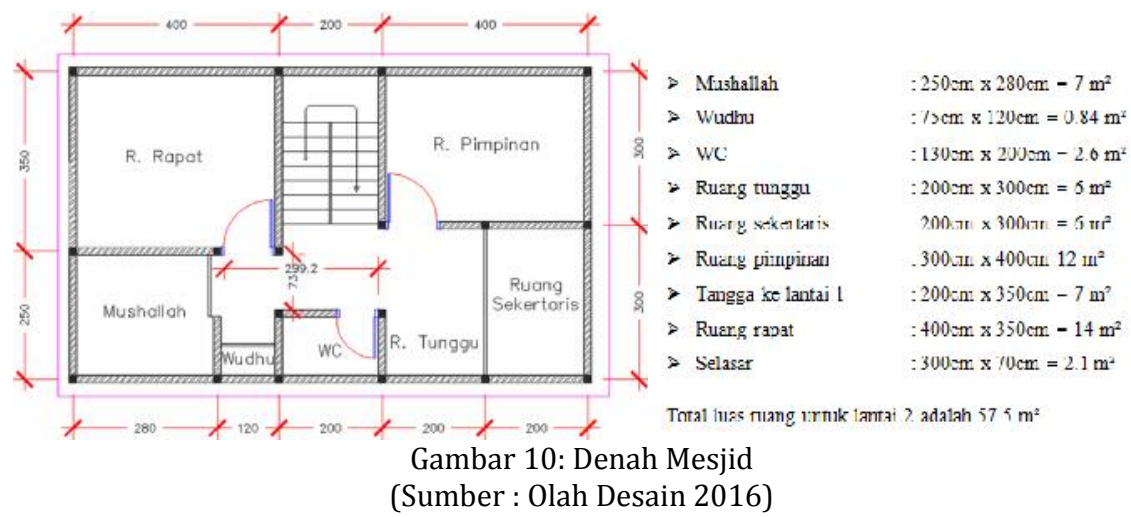

Tabel .1 Gagasan akhir pemanfaatan lahan

\begin{tabular}{|c|c|c|}
\hline Nama Bangunan & Unit Bangunan & Total Luas $\mathbf{m}^{2}$ \\
\hline Kios Grosir & 6 & 1944 \\
\hline Lantai 1 & 6 & 1944 \\
\hline Lantai 2 / Lantai mini & 6 & 678 \\
\hline Mesiid & 1 & 65 \\
\hline Kantor Pengelolah & 1 & 114 \\
\hline Lantai 1 & 1 & 114 \\
\hline Lantai 2 & 1 & 57.5 \\
\hline Gudang & 5 & 1440 \\
\hline Rumah Makan & 1 & 360 \\
\hline Pos Iaga & 2 & 20 \\
\hline Ruang Terbuka dan Pengembangan & & 46451 \\
\hline Total & & 50394 \\
\hline
\end{tabular}

Sumber: Olah Data

Dari data tabel di atas dapat di simpulkan sebagai berikut : Luas keseluruhan tapak perancangan : $50394 \mathrm{~m}^{2}$

Presentase terbangun dan area pengembangan : $15118 \mathrm{~m}^{2} / 50394 \mathrm{~m}^{2} \times 100=29.9=30 \%$.

Luas area terbuka dan pengembangan : $50394 \mathrm{~m}^{2}-15118 \mathrm{~m}^{2}=35276 \mathrm{~m}^{2}$

Presentase $=35276 \mathrm{~m}^{2} / 50394 \mathrm{~m}^{2} \times 100=70 \%$

Hasil perhitungan di atas dari segi pemanfaatan lahan, desain pasar telah sesuai dengan pemanfaatan lahan yaitu sebesar 30\% untuk area terbangun dan area pengembangan dan menyediakan $70 \%$ untuk area atau kawasan terbuka hijau.

\section{KESIMPULAN}

Perancangan Pasar Agrobisnis dengan Konsep Vernakular pada desain lebih banyak menampilkan unsur alami. Building coverage ratio sebesar 30 : 70, dimana 30\% di rencanakan untuk lahan bangunan, dan $70 \%$ dgunakan untuk lahan tidak tebangun untuk menyediakan banyak ruang terbuka dalam tapak. Bentuk bangunan dan pintu gerbang merupakan hasil pengembagan dari bentuk dasar dari rumah panggung Bugis Makassar. 


\section{DAFTAR PUSTAKA}

Ferdyansah. 2010. Eksistensi Pasar Induk Puspa Agro dalam Perspektif Pemangku Kepentingan. Skripsi Universitas Pembangunan nasional Veteran.

Haryadi, B. Setiawan. 2013. Arsitektur Lingkungan dan Perilaku.

Henstin Mulyandari. 2011. Pengantar Arsitektur Kota.

Peraturan Daerah Kota Makassar Nomor 6 Tahun 2006 Tentang Rencana Tata Ruang Wilayah Kota Makassar 2005-2015.

Perda RTRW Kota Makassar 2010 - 2030

Robert J. Kodoatie dan Roestam Sjarief. 2010. Tata Ruang Air.

Irsad, MS. 2002. Pasar Agribisnis di Makassar. Skripsi Teknik Arsitektur Universitas 45.

Ni Made Winda Roosdiana Devi. 2011. Pasar Umum Gubug Di Kabupaten Grobogan dengan Pengolahan Tata Ruang Luar dan Dalam Melalui Pendekatan Ideologi Fungsionalisme Utilitarian". Skripsi.

Keputusan Menteri Kesehatan Republik Indonesia Nomor : 519/menkes/sk/vi/2008 Tentang Pedoman Penyelenggaraan Pasar Sehat. Akses: 06-10-2015

Kamus Besar Bahasa Indonesia (KBBI) Online Internet. Peraturan Presiden Repoblik Indonesia. no.112 th. 2007 http:/m.hukumonline.com .Minggu, 25-10-2015.

Internet Senin,18 Mei 2015/10:45. Pembangunan Pasar Induk Agribisnis di Jawa Timur www.d-infokom-jatim.go-id Prioritas- Agribisnis. Asp.

Internet, Muhammar Khamdevi. Associate of Indonesian Professional for Science, Technology and Enterprises" (AIPSE). Email www.m.khamdevi(at) yahoo.com (Sabtu,13-0315/21:00).

Internet, Pemda Dinas Pengelola pasar Kota Makassar, "Revisi Rencana Umum Tata Ruang (RUTRI) Kota Makassar Tentang Pasar" (Senin,18-05-2015/11:05).

Internet .Menteri Perdagangan Republik Indonesia. www.kemendag.go.id , (Minggu, 25-10-2015)

Firdaus (2010) http:/diardamara.blogspot.co.id ( Rabu, 11-11-1015)

Internet. Arsitektur dan Kebudayaan Kesenian Indonesia. (11 April 2011) https://id.m.wikipedia.org/wiki/Arsitektur/Indonesia (Rabu, 11-11-2015)

Internet. Pasar Tradisional Terkenal di Indonesia. http:/m.detik.com (Rabu, 11-11-2015)

Internet. Konsep Jual Beli Dalam Hukum Islam. http://digilib.uinsb y.ac.id (20 November 2015)

Internet. Potensi Hasil Pertanian di Sulawesi Selatan. http://ten-teng- maros.blogspotco.id/2011/04potensi-hasil-pertanian-di-sulawesi.html?m=1 (20November 2015)

Internet "Geografis Kota Mkassar" http://makassarkota.go.id/110- geografiskotamakassar.html. 